\title{
AN ANTHROPOLOGICAL INSIGHT ON THE COMMONALITIES BETWEEN TOURISM AND ARCHAEOLOGY
}

\author{
Maximiliano KORSTANJE ${ }^{1}$ \\ University of Palermo, Argentina \\ ORCID: 0000-0002-5149-1669
}

Over the years, archaeology maturated towards something else than a scientific discipline. Archaeological sites are culturally showed as emerging and recycled tourist attractions (Robb, 1998; Bateman, 2006; Rowan \& Baram, 2004; Karlsson \& Gustafsson, 2006). At a closer look, tourism is understood as a leisure activity which is enrooted in the needs of relaxing and evasion while archaeology - as a knowledge platform which is based on scientific method - explores the history of ancient cultures. This raises a more than interesting question respecting the commonalities and differences between archaeology and tourism. To some extent, archaeologists find ancient relics and objects which not only belonged to "Others" who have perished but -and what is more important- have no sense beyond the borders of archaeological knowledge. At the same time, tourists visit archaeological ruins which are interpreted according to the social imaginary which was filled by archaeologists (Cohen, 1985; Rubio, 2006). As Korstanje (2012) puts it, the notion of history has been historically criticized to be functional to the imperial order. The first ethnologists developed a paternalist viewpoint to understand the non-western "Other". Based exclusively on the beliefs that the pre-modern Europe disappears once industrialism advanced, the ethnographers and field-workers strongly believed the aboriginal world would be in the bias of extinction (Stocking, 1968). The needs of protecting

\footnotetext{
1 Address Correspondence to Maximiliano Korstanje, Department of Economics, University of Palermo, ARGENTINA. E-mail: maxikorstanje@arnet.com.ar
} 
them associated with the urgency to collect relics, lore, utensils, artefacts as well as oral-stories and myths led fieldworkers to document everything they experienced or simply met. Paradoxically, the produced information was employed by the colonial officers to domesticate the aborigines (Boas 1904). Any travel is a foundational act of conquest (Clifford, 1988). To put the same in bluntly, the advances of science were politically manipulated to keep the centre-periphery dependency (Harris, 2001). From its onset, archaeology adopted a linear vision of the time which was ideologically marked by the evolution theory. Societies were framed as organisms which evolve in the time towards a maturate form. The agrarian life will irreversibly be overwhelmed by industrial capitalism. While protecting means preserving this reason emphasized the needs of creating museums to locate the collected relics. This double tension ascribed to the fact that archaeology and anthropology situated as scientific options studying nonwestern cultures at the time little attention was paid to "the own nesting in western ethos" (Edgeworth, 2006). In this respect, archaeology valorises other ancient cultures elaborating its own discourse about how these perished aboriginal communities lived. To a major or lesser degree, the non-western "Other" is excluded from the formation of archaeological discourse. The notion of identity is unilaterally oriented to delineate the borders of an emptied encounter. While tourists interact -to some extentwith natives, this does not happen with archaeologists who often imagine the functionality of object they came across. However, both tourism and archaeology are symbolically embedded into the same cultural matrix which gives legitimacy to the organization of modern capitalism around the cultural values of novelty, uniqueness and exemplarity. Archaeology cements the knowledge imagining other conditions which are certainly closed and inexpungable to tourists but at a first glimpse, both look for the ideals of uniqueness. While the research's success depends upon the originality of the ancient relic, the tourist-gaze (citing Urry, 2002) is in quest of something new to possess. The ideals of control, protection and classification which resulted from the colonial enterprise still remain in tourism consumption. The archaeological object is classified by its intrinsic value which exceeds the monetary transaction. In fact, these objects are valueless. Tourists expropriate the gazed landscape through the introduction of the camera, while archaeologists introduce another technological instrument to construct the same one-sided view of the world. Archaeology looks to reconstruct those lost worlds anthropology vaticinated but tourists finally consume a much deeper idealized and mirroring landscape that interrogates their own existence. This process of reflexibility is partially given by the "nothingness" which means the lack 
of any interaction between the selfhood and the alterity. Like museums, not only the archaeological sites are spaces of death but they have no dwellers, no natives, and no life. This cultural appropriation cannot be achieved without the process of sacralisation which precedes tourism consumption. Equally important, archaeology provides cultural tourism industry with the commodities to function. Visitors and archaeologists and perhaps this is the moot-point to debate- are obsessed by authenticity. As Thomas Yarrow (2006) puts it, from its inception archaeology has been denounced by a lack of reflexibility with the local agency. This suggests that social interaction seems to be a real obstacle for archaeologists and once the desired object is found they come back home. The instrumentalization of the non-existent "Other" plays a crucial role in the objectivity of the knowledge production of archaeology. Hence the created ideological discourse rests on a false interpretation of the past. Most certainly, the logic of discovery has no sense without the production and fabrication of codes and interpretations. The idea of authenticity gives accuracy to these symbolic frameworks. To put the same in other terms, authenticity echoes the dominant discourse of the colonial rule which divides the world in two: those cultures to be preserved and those which should be discarded. The technology of mystification that prompted the creation of museums endorses value to some (relics) object while others are covered. Annette Weiner (1992) discovered how the aboriginal relics are often sacralised to become "alienable things" which are excluded from the marketplace and the mutual exchange. The copycat establishes a dialectical relation with the authentic object. The exchanged objects, aligned with the logic of the market, reconstructs the cycle of social reciprocity. While these objects are copycats, the foundational authentic object is preserved in the core of society as an "inalienable thing". The same confrontational relation applies for museums and what Dean MacCannell dubbed as "staged authenticity". MacCannell (1976) alerts that the interest of visitors for consuming authenticity is directly proportional to the creation of staged-authenticity. Archaeology looks for the reconstruction of an ancient culture. The discipline is in quest of the truth but in so doing, paradoxically the "non-western Other" is arbitrarily reconfigured according to the proper ethnocentrism of archaeologists and fieldworkers.

This short commentary piece is not aimed to exert a radical criticism on cultural tourism but in evincing the connection of the cultural consumption and the colonial logic. MacCannell is right when he confirms tourism occupies the place of the totem in aboriginal cultures, as a 
mediating process that led the alienated workers and their political institutions. The tourist-gaze needs from the ideological message that reminds its superiority over other (perished) cultures (Urry, 2002). This sense of exceptionality seems to be determined by the quest of novelty. Museums, which act as political artefacts of control, exhibit two significant aspects of the phenomenon. On one hand, it signals to the needs to control the pastime to organize the labour in modern capitalism. On another, echoing Mary Louise Pratt (2007)- the imperial eyes are moved to travel to overseas territories to mark non-western others while they avoid being marked. To say the same in other terms, the needs of protecting others equates some assumption the proper culture is superior, stronger or more sophisticated. This evinces that far from being naïve persons -as Boorstin said- and archaeologists an authoritative voice, both represents a dialectical tension of exchangeable agents within the constellations of imperialism.

\section{REFERENCES}

Bateman, J. (2006). Pictures, ideas, and things: the production and currency of archaeological images. In M. Edgeworth (Ed.), Ethnographies of Archaeological Practices (pp 68-80). Lanham: Altamira Press.

Boas, F. (1904). The history of anthropology. Science, 20(512), 513-524.

Clifford, J. (1988). The Predicament of Culture: Twentieth-Century Ethnography, Literature, and Art. Massachusetts: Harvard University Press.

Cohen, E. (1985). The tourist guide: The origins, structure and dynamics of a role. Annals of Tourism Research, 12(1), 5-29.

Edgeworth, M. (2006). Preface. In M. Edgeworth (Ed.), Ethnographies of Archaeological Practices. Lanham: Altamira Press

Harris, M. (2001). The rise of anthropological theory: A history of theories of culture. New York: Rowman Altamira.

Karlsson, H \& Gustafsson, A. (2006). Among Totem Poles and Clan Power in Tanum, Sweden. In M. Edgeworth (Ed.), Ethnographies of Archaeological Practices (pp 137147). Lanham: Altamira Press.

Korstanje, M. (2012). Reconsidering cultural tourism: An anthropologist's perspective. Journal of Heritage Tourism, 7(2), 179-184.

Maccannell, D. (1976). The tourist: A new theory of the leisure class. Berkeley: University of California Press.

Pratt, M. L. (2007). Imperial eyes: Travel writing and transculturation. Abingdon: Routledge.

Robb, J. G. (1998). Tourism and legends archaeology of Heritage. Annals of Tourism Research, 25(3), 579-596.

Rowan, Y. M., \& Baram, U. (Eds.). (2004). Marketing heritage: Archaeology and the consumption of the past. Rowman Altamira. 
Rubio, S. P. (2006). La ciudad fingida. Representaciones y memorias de la Barcelona turística. Pasos. Revista de turismo y patrimonio cultural, 4(1), 13-28.

Stocking, G. W. (1968). Race, culture, and evolution: Essays in the history of anthropology. Chicago: University of Chicago Press.

Urry, J. (2002). The tourist gaze. London: Sage.

Weiner, A. B. (1992). Inalienable possessions: The paradox of keeping-while-giving. Berkeley: University of California Press.

Yarrow, T. (2006). Sites of Knowledge: Different ways of knowing an archaeological excavation. In M. Edgeworth (Ed.), Ethnographies of Archaeological Practices (pp. 20-32). Lanham: Altamira Press. 